MYKOL ROMERIO
UNIVERITEIAS

\title{
VERTYBĖS DVASINGUME IR DVASINGUMO VERTYBĖS
}

\author{
Saulius Kanišauskas \\ Mykolo Romerio universiteto Humanitarinių mokslų instituto \\ Filosofijos katedra \\ Ateities g. 20, LT-08303, Vilnius, Lietuva \\ Telefonas (+ 370 5) 2714628 \\ Elektroninis paštas sauliusk@ml.lt
}

Pateikta $2013 \mathrm{~m}$. balandžio $12 \mathrm{~d}$., parengta spausdinti $2013 \mathrm{~m}$. liepos $20 \mathrm{~d}$.

doi:10.13165/SMS-13-5-3-02

Anotacija. Straipsnyje analizuojama dvasingumo samprata. Ji siejama su prof. A. Mureikos pasiūlyta p a $j$ a u to s koncepcija, skleidžiama per žmogiškuju vertybiu sistema ir gyvenimo prasmès paieškas. Vertybiu nuvertëjimas - viena iš didžiausiu dabarties problemu. Dvasingumo ugdymui reikalinga universali dvasingumo samprata. Issakoma mintis, kad dvasingumas yra Šventenybès p a j a u t a - tiek igimta, tiek igyta. Siekiant ta pajauta išugdyti ir išsingdyti, reikia keisti büsimu pedagogu rengimo sistema.

Reikšminiai žodžiai: dvasia, dvasingumas, vertybès, dorybès, pajauta, Šventenybè.

\section{Irvadas}

Dvasia ir dvasingumas - tai žodžiai, kuriuos vartojame vos ne kasdieną ir vargu ar suprantame, greičiau tik nujaučiame, ką jie reiškia. O tos „nuojautos“ gan skirtingos, kaip ir bandymai juos apibrěžti racionaliai. Tuo teko įsitikinti $2010 \mathrm{~m}$. kovo 18 d. dalyvaujant Kuršènuose ịvykusioje mokslineje konferencijoje „Dvasingumo 
sklaida ugdymo realybejje“"1 ir Lietuvos Respublikos švietimo ir mokslo ministerijos 2010 m. gruodžio 21 d. organizuotoje Viešojoje konsultacijoje-diskusijoje „Dvasinis ugdymas: švietimo įstaigų vaidmuo“2. Nors tiek konferencijoje, tiek konsultacijojediskusijoje, kurioje greta pedagogų ir andragogų dalyvavo dvasininkai, rašytojai, socialiniai darbuotojai, filosofai ir t. t., buvo kalbama tarsi apie tą pati, bet kiekvienas pranešejas ir išsakiusieji savo nuomones, dejuodamas dẻl tarp jaunimo plintančio vertybiu nuvertẻjimo ir vienokiu ar kitokiu aspektu pabrèždamas, jog dvasines vertybes èmė užgožti ị hedonistinių poreikių tenkinimą orientuotos grynai materialios, instrumentinès vertybès, kad èmė ryškèti dvasingumo devalvacija, taip ir nepasakè, kas tas dvasingumas ar bent kaip pats jị supranta. Kiek prisimenu, ne išimtis buvau ir aš, ir nors dvasingumo sampratą siejau su F. Varelos autopoiesis teorija, bet aiškaus šios sąvokos apibrèžimo nè nebandžiau pateikti.

Grịžti prie dvasingumo problemos paskatino mūsų (Mykolo Romerio) universitete Filosofijos katedros suorganizuota mokslinè konferencija „Vertybės filosofijoje ir filosofijos vertybès“. Grynai asociatyviai kilo mintis: o kodèl gi nepamąsčius ne apie vertybes filosofijoje ir filosofijos vertybes, o apie vertybes dvasingume ir dvasingumo vertybes?! Nes tai, ką vadiname dvasingumu, visais laikais buvo ir yra laikoma kone aukščiausia vertybe, ir dvasingumas skleidžiasi per žmogiškas vertybes. Pagaliau ar filosofinè refleksija nepadètų atsakyti ị klausimą, kas yra tas dvasingumas ir kaip jị ugdyti?

Štai šie spontaniškai kilę klausimai ir tapo tiek pranešimo konferencijoje, tiek šio straipsnio paskata.

Jau yra įprasta išsyk apsibrèžti aptariamos problemos svarbą ir darbo tikslus. Kas dèl svarbos, tai jau atkreipiau dèmesį, jog vis labiau plinta nerimas dèl vertybių nuvertèjimo, dvasingumo devalvacijos. Turiu omenyje ne vien iš žiniasklaidos „lūpu““ plūstančią informaciją apie nusikaltimus, nepagarbą teisei ir teisingumui, abejingumą piktadarybėms, motinų paliktus vaikus ir vaikų paliktus tėvus bei daugybę kitų bėdų. Turiu omenyje ir širdi stingdantị bei siaubingai greitai plintantị susvetimèjimą tarp mūsų, kai naujausios informacinès technologijos atvėrè neribotas galimybes bendrauti, o tame bendravime ima nelikti nedrąsios šypsenos, atidaus ar švelnaus žvilgsnio, rankos prisilietimo, ima nelikti nieko intymaus, šilto ir betarpiško, kupino noro atjausti ir užjausti, kupino noro padèti.

Šie ypač vyresnès kartos žmonėms ryškiai pastebimi procesai kelia nerimą. Be abejo, galima prisiminti, kad ir šumerai skundèsi savo jaunimo ištvirkimu, tad galètume nurimti tardami, jog nieko naujo po šia saule nėra, ir dabartinis mūsų niurzgejjimas dèl dvasingumo stokos yra tuščias ta prasme, kad ir mūsų vaikaičiai ir vaikaičių vaikaičiai niurzgès, kad jų vaikai esą nedori, nedvasingi. Bet tokio tipo optimizmas labai panašus ị stručio elgesi pavojaus akivaizdoje - paslèpus galvą smėlyje ir nieko nematant pavojaus tarsi nelieka ${ }^{3}$. O jis vis dèlto egzistuoja - ne viskas gerai mūsų visuomenèje,

1 Janulytė, E. Dvasingumo sklaida mažuose miesteliuose. XXI Amžius. 2010 m. balandžio 23, Nr. 31 (1816).

2 Dvasinis ugdymas:švietimo įstaigų vaidmuo [interaktyvus]. [žiūrèta2013-04-22]. <http://www.smm.lt/ strategija/docs/Dvasinis\%20ugdymas_PROGRAMA_2010-12-21.pdf>.

3 Dabar puikiai žinoma, jog stručiai taip nesielgia, bet stručius ,šmeižiantis“ posakis išliko iki šiol, tapo vaizdžia metafora, tad ją vartoju ir aš. 
tikrai ne viskas! Ir jau vien todèl dvasingumo ir vertybių problemos šiuo metu yra ne tik aktualios, bet ir nepaprastai, tiesiog gildančiai svarbios.

Ir išsyk išsakysiu savo esminị teiginį - dvasingumo ugdymo problemos neišspręsime tol, kol nesuvoksime to, kas dvasingumo sampratoje yra svarbiausia.

Šio straipsnio tikslu ir laikau bandymą apibrèžti dvasingumo esmę bei pateikti iš tos esmès išplaukiančius kai kuriuos konkrečius siūlymus, kaip dvasingumą ugdyti.

\section{Dvasingumo sampratos}

Nors dvasios ir dvasingumo sąvokos vartojamos vos ne kasdien, bet ir „visažinis“ internetas menkai man galejjo padèti. Straipsnių ir straipsnelių, net tokių, kuriuose $d v a-$ singumas siejamas su mịslinga psichine energija, o pastaroji apibūdinama ne mažiau mịslingomis magnetinèmis savybėmis, apstu, bet aiškaus ir vienareikšmio dvasingumo apibrėžimo bent iki šiol neradau. Jie visi šiek tiek panašūs, ir jie visi ganėtinai skiriasi. Panašūs tuo, kad dvasingumas siejamas su dvasios buvimu ir turèjimu, o dvasia siejama su gyvybingumu, gyvastingumu. Neiškentęs pasižiūrèjau ir ị dabartinès lietuvių kalbos žodyną ${ }^{4}$ - gal aš, lietuvis, savos kalbos gerai nepažịstu, o todèl ir nesuprantu, kas yra ta dvasia ir kas yra dvasingumas? Prieš tą padarant pagalvojau: juk žodžiai dvésti, nudvésti yra susiję su žodžiu dvasia! Kai gyvulys nudvesia, jis netenka dvasios, paprasčiau sakant, miršta. Tad nesunku suvokti, kad mirtis yra siejama su dvasios praradimu, netekimu. Nesunku suvokti ir tai, kad žodžiai numirti ir nudvésti byloja apie tai, kad jau mūsų protėvių protèviai suvoké, jog žmogus ir gyvulys esmingai skiriasi. Todèl ir sakoma, kad žmonès miršta, o gyvuliai dvesia, nugaišta, nustimpa. Tačiau tiek mirtis, tiek nudvėsimas reiškia gyvybès netekimą. Iš čia natūraliai darytina išvada, kad dvasia pirmiausia turi būti siejama su gyvybe, gyvastingumu. Atsivertus žodyną paaiškëjo, kad taip ir yra. Tiesa, mūsų protèviai (ne tik mūsų, o ir visų tautų) gyvybę siejo su kvėpavimu (kol gyvas - kvėpuoji), o mirti - su šios gyvybinės funkcijos netekimu, tad žodynuose pirmapradė žodžio dvasia reikšmė siejama su tuo, kas iškvepiama, išdvesiama. Dvasia atitinkantis rusiškas žodis $\partial y x$ irgi kildinamas iš žodžio kvépuoti, t. y. doımamb. Homero laikais graikai tai, ką mes vadiname dvasia, vadino daimonu, vèliau ji tapatino su aukščiausia psichine jèga, arba kosminès prigimties protu, kurị Heraklei-

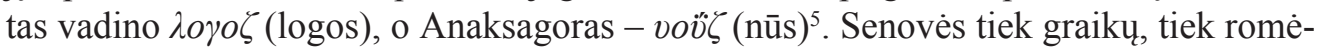
nų stoikai tai, ką mes vadiname dvasia, vadino pneuma (ši žodị ị lotynų kalbą išvertè žodžiu spiritus) ir pneuma (spiritus) siejo su dvelksmu, alsavimu, kvėpavimu, gyvastingumu. Tiesa, šie filosofai pneumą laikè esant kosminès prigimties subtiliaja materija, kuri viskam suteikia gyvybę ir ją palaiko, ir būtent pastaroji samprata, atsisakius joje implikuoto (tebūnie, ir ,,subtilaus“") materialumo, krikščionybèje ịgijo transcendentinę (idealią, antgamtinę) dimensiją. Vèliau dvasios ir dvasingumo sampratos dar labiau pakito (žr. toliau), bet visose jose išliko ir pirmapradè - gyvybès, gyvastingumo.

4 Dabartinès lietuvių kalbos žodynas. Ats. redaktorius J. Kruopas. Vilnius: Mintis, 1972.

5 Šis graikiškas žodis į kitas kalbas transkribuojamas ir kaip nūs, ir nus, ir nous, ir noos. Iš pastarosios transkribcijos kildinamas žodis noosfera (t. y. proto sfera). 
Bet jeigu dvasia siejama su gyvybe, tada reikia klausti, iš kur ta gyvybė kyla, koks jos šaltinis? Taip klausiant išsyk tenka pereiti ị filosofijos sriți. Nes mokslas, nors ir pateikęs bent kelias gyvybès kilmès versijas, ị ši klausimą kol kas ịtikinamo atsakymo dar nedavè. Filosofai to irgi nepadarè. Teisingiau sakant, filosofiniame diskurse istoriškai susiklostė dvi galingos tékmès, kurių kiekviena bandè ir bando ịrodyti savosios versijos tikrumą, bet to padaryti iki šiol nepajègé, juolab kad ir tose tèkmėse esama daugybè srovių ir srovelių. Tradiciškai šios tèkmès vadinamos idealizmu ir materializmu, arba spiritualizmu ir realizmu ${ }^{6}$. Idealizmo ir spiritualizmo terminai nèra tapatūs jau vien todèl, kad iš Platono filosofijos kilęs pirmasis akcentuoja abstrakčias idejas, o antrasis siejamas su dvasia, dvasingumu (lot. spiritus reiškia dvasia) ir kur kas dažniau vartojamas religiniuose diskursuose, teologijoje, misticizme nei filosofijoje. Bet abu šie terminai siejami su mintimi, kad tikrovès esmè esanti ideali, dvasinè, o ne materiali. Kai kalbama apie dvasinguma, tai tradiciškai ir pirmiausiai šis terminas siejamas su religiniais žmonių įsitikinimais ir išgyvenimais bei tikejjimu dvasine žmogaus prigimtimi. Kita vertus, kartu su industrializacijos pradžia prasidejjus sekuliarizacijai (ši terminą ị socialinị diskursą ịvedè M. Weberis kaip antipodą sakralinei kultūrai $\left.{ }^{7}\right)$ dvasios terminas imtas vartoti kultūros prasme (,tautos dvasia“, „mokslo dvasia“ ir pan.), o dvasingumas imtas sieti su kultūringumu, pastaraji pirmiausiai suprantant priimtų tarpusavio bendravimo taisyklių laikymosi, išsimokslinimo, kūrybingumo prasme.

Dvasingumo sampratos kaitos istoriją nagrinèjęs A. Vaišvila teigia, kad tai yra ne kas kita, kaip dvasingumo termino demistifikacijos istorija, ir ši procesą jis sieja su kultūrologiniu to termino ịprasminimu. Atkreipęs dèmesị ị tai, kad dvasios problema visais laikais egzistavo ir tebeegzistuoja kaip savaiminio judejjimo (gyvybingumo) problema, jis tvirtina, kad ir dvasios definicija yra perejusi bent keturias savo istorinio tapsmo stadijas: biologizacijos, logizacijos, psichologizacijos ir kultūrologizacijos ${ }^{8}$.

Pasak A. Vaišvilos (truputi ji perfrazuojant), biologizacijos etape dvasingumas (dvasia) buvo tapatinamas su gyvybe apskritai, manant, jog visa gamta yra gyva (tai priskirtina hilozoistinèms, animistinèms tikrovès sampratoms), logizacijos etape, kurio pradžia siejama su Platono ir Aristotelio filosofija, dvasios (sielos) esmè buvo tapatinama su protu, psichologizacijos etape, kurio ištakos regimos B. Pascalio „,̌irdies kalboje“, dvasingumas siejamas su žmogiškais jausmais, išgyvenimais, ir pagaliau atėjo kultūrologinè, sociologine dvasingumo samprata, kai dvasingumas pradètas tapatinti su žmogaus kūrybinėmis galiomis, jo gebejjimais keisti ir perkeisti gyvenamają aplinką.

Iš esmès sutikdamas su ịvardintais dvasingumo sampratos kaitos etapais, juo labiau, kad pats autorius pabrèžia jų sąlygotumą, vis dèlto noriu atkreipti dèmesị ị tai, kad ir dabartyje niekur nedingo ir psichologinè, ir loginè, net hilozoistinè bei animistinè dvasios bei dvasingumo sampratos. Dvasingais vadiname ir tuos žmones, kurie savo protu bei meniniais gebejjimais geba pasiekti kūrybines aukštumas, ir tuos, kurie geba

6 Nesunku parodyti, kad save realistais vadinantys dabartiniai mokslininkai ir filosofai faktiškai vadovaujasi materialistine ontologija.

7 Jacopozzi, A. Religijos filosofija. Vilnius: Aidai, 1997, p. 105.

8 Vaišvila, A. Kultūrologinè dvasingumo samprata. Šiuolaikine filosofija: globalizacijos amžius. Sudarytoja ir ats. redaktorè J. Morkūnienè. Vilnius: Lietuvos teisès universitetas, 2004, p. $72-87$. 
kalbėti „širdies kalba“ bei girdèti „,̌irdies ausimis“, kurie kupini atjautos, pagarbos kitam žmogui ir gyvybei apskritai, kurie geba išlikti orūs net ir sunkiausiomis sąlygomis. Tai, ką vadiname dvasia, ir šiandieną yra siejama su gyvybine, su psichine energija, pagaliau su tuo pirminiu, grynu pavidalu, kuris viskam suteikia gyvybės, jausmo, proto prada, kuris krikščionybejje vadinamas Šventaja Dvasia. Todėl teigti, kad dabartyje vyrauja tik kultūrologinè dvasingumo samprata, vargu ar teisinga.

Kita vertus, jau minèjau, jog kalbant apie dvasingumą dažnai nesusikalbama. Regimai, taip yra todèl, kad skirtingi asmenys dvasingumą supranta ganètinai skirtingai ar bent pabrėžia skirtingus šios sąvokos aspektus. Vargu ar reikia tuo stebėtis, nes jau minèjau, kad vieno terminų dvasia ir dvasingumas apibréžimo nėra. Tuo nesunku įsitikinti panaršius po internetą, nesunku įsitikinti ir bent pavarčius didžiulès apimties kolektyvią monografiją „Dvasingumas žmogaus pasaulyje“" - kiek autorių, tiek ir dvasingumo sampratų. Jos ganėtinai panašios, bet ir ganėtinai skiriasi, todèl suprasti, kas tas $d v a-$ singumas, yra sunku. Net, mano manymu, pačiame įžvalgiausiame Juozo Mureikos analitiniame straipsnyje ${ }^{10}$ apstu dvasingumo dimensiją referuojančių predikatų, kurias jis vadina egzistencialijomis, tokių, kaip tikejjimas, meile, viltis, laisve, atsakomybe, ilgesys, grožis, gèris, tiesa, šventumas, nuostaba, dèmesys, atjauta, rūpestis, atlaidumas, pasiaukojimas, simpatija, laimé, malonumas, altruizmas, bendrysté, kančia, draugystè, tolerancija, džiaugsmas, drąsa, pagaliau ir šių terminų opozicijų, bylojančių, jog anaiptol ne visiems žmonèms būdingos ịvardintos dorybès, t a č i a u nei dvasios, nei dvasingumo apibréžimu neradau. Bent man liko neaišku ir tai, kas yra svarbiausia įvardintoje dvasinés veiklos, arba dvasiniu galiu, struktūroje: ar valia veikti, ar motyvacija, ar prasmè, ar atmintis, mąstymas, kalba, vaizduotè, fantazija, apsisprendimas, igyvendinimas, o gal tai, ką J. Mureika vadina pajauta? Didžiojoje daugumoje kitų šios monografijos straipsnių, išskyrus Olgos Oleksiuk ${ }^{11}$, irgi ịvardijamos su dvasingumu siejamos ịvairios dorybés (ar jų stoka), bet ir ten ị klausimą, kas yra tas nuolat minimas dvasingumas ir kas yra ta dvasia, atsakymo nerasime.

Tad gal šių žodžių prasmès apibrėžti išvis neįmanoma? Gal žodis dvasia yra toks pat nedeskribuojamas, kaip ir žodis gėris, kaip ir žodžiai baltas, mèlynas, geltonas? Gal vertètų pasitenkinti tik intuityviu to žodžio suvokimu? Ko gero, būtent tokią išeitị mums būtų pasiūlęs G. Moore'as...

Vis dèlto pabandysiu šių žodžių - dvasia ir dvasingumas - prasmés paieškoti. Juolab kad jie tiek religiniame, tiek sekuliariame diskursuose vartojami vos ne kasdieną, kad jų šaknys glūdi neịsivaizduojamai gilioje praeityje.

O. Oleksiuk įvardija bent kelias d a b a $\mathrm{r}$ t i n e s dvasingumo sampratas. Jos daugiau ar mažiau sutampa su tomis, kurias paminėjo A. Vaišvila, bet ši autorè neakcen-

9 Dvasingumas žmogaus pasaulyje. Sudarytojai ir rengèjai J. Kievišas, R. Kondratienė. Vilnius: Vilniaus pedagoginio universiteto leidykla, 2009.

10 Mureika, J. Dvasingumas ir prasmè. Dvasingumas žmogaus pasaulyje. Sudarytojai ir rengèjai J. Kievišas, R. Kondratienè. Vilnius: Vilniaus pedagoginio universiteto leidykla, 2009, p. 46-87.

11 Oleksiuk, O. Konceptualūs asmenybės dvasingumo formavimo meno srityje pagrindai. Dvasingumas žmogaus pasaulyje. Sudarytojai ir rengèjai J. Kievišas, R. Kondratienė. Vilnius: Vilniaus pedagoginio universiteto leidykla, 2009, p. 154-167. 
tuoja jų kilmės istoriškumo. Atvirkščiai, ji pabrèžia, kad nepaisant to, jog daugumos jų ištakos nepaprastai senos, visos jos yra šiuolaikinės.

Bene geriausiai yra žinoma iki šiol išlikusi religine dvasingumo samprata - $d v a-$ singumas apibrěžiamas kaip veržimasis prie Dievo, gilus priklausomybès anapusiniam pasauliui jausmas. Filosofo M. Mamardašvilio darbuose dvasingumas - tai ne tik ypatinga ideali (,,antgamtine ${ }^{6}$ ) realybe, bet ir ypatinga veikla, per kurią iškyla idealumas. Filosofinèje antropologijoje (konkrečiai - M. Schelerio bei N. Hartmano darbuose) vyrauja požiūris, kad dvasingumas - tai ne substancija; dvasia, egzistuojanti žmogiškos būties dvasinių aktų pavidalu, kurių šaltinis ir nešèjas yra žmogus kaip dvasinga būtybè. Panašus yra ir logoterapijos kūrèjo V. Franklio požiūris. Dvasingumą jis sieja su žmogaus veiklos intencionalumu, su žmogaus gebejjimu savitranscendentuoti, su sąmonès orientacija tiek ị esmingumą, tiek ị išorinius objektus. Humanistinę dvasingumo sampratą pateikè šiuolaikiniai rusų filosofai V. Fedotova ir J. Ponomariovas: bet kokia dvasingumo aktualizacija susijusi tik su žmogui prieinamomis aukščiausiomis dvasinėmis vertybėmis. Kitas žymus rusų filosofas S. Krymskis dvasingumą apibrèžia kaip žmogaus savikūros principą, kaip iššūkị baigti tai, kas nesibaigia natūraliu būdu, ir šis apibrėžimas bene artimiausias kultūrologinei dvasingumo sampratai. Pagaliau iki šiol nepamirštama ir energetine dvasingumo koncepcija - tiek materialistine ontologija besivadovavusio V. Vernadskio, kuris paskelbè noosferos koncepciją, tiek spiritualistine dvasia šią koncepciją išplètojusio prancūzų paleontologo ir dvasininko bei filosofo P. Teilhard de Chardino ${ }^{12}$. Pati O. Oleksiuk dvasingumą apibrèžia kaip asmenybès gebejjimą išreikšti savo vidinès būties universalumą ir teigia, kad dvasingumas susijęs su žmogaus aktyviu siekiu rasti savo egzistavimo prasmę, prisijungti prie kultūros dvasinio Universumo. Pastaraji ji supranta rusų pansociokosmizmo filosofijos (N. Fiodorovo, K. Ciolkovskio, V. Vernadskio ir kt.) dvasia, t. y. kaip žmogaus ir kosminių kūrybinių jègų sąveikos rezultatą.

Nors P. Teilhard de Chardino teikta noosferos koncepcija Katalikų Bažnyčios pagaliau ir buvo priimta kaip viena iš galimų krikščionybei neprieštaraujančių onto$\operatorname{logijų~}^{13}$, bet joje esantis gan ryškus panenteistinis pradas sekuliarizuotos dvasingumo sampratos gynèjams leidžia ja savotiškai piktnaudžiauti - religinis metmuo čia ,išplaunamas“, ir lieka tik su dvasingumu siejamos kažkokios „kosminès energijos“, kurias tikimasi užfiksuoti žmogaus sukurtais prietaisais.

Diskusijos dèl tikrovès hierarchinès prigimties ir galimybės tai, kas vadinama $d v a-$ singumo raiška, redukuoti ị informacinėmis technologijomis aprašomus fizinius procesus, ne tik tęsiasi, bet ir ganètinai pagyvèjo. Ima aiškèti, kad žmogaus kultūrinè veikla gan reikšmingai veikia tai, kas vadinama genetiniu kodu, ir atvirkščiai ${ }^{14}$. Ima ryškèti, kad ne pats savaime genetinis kodas kaip itin sudètinga molekuliu struktūra lemia gyvybines funkcijas ir protavimo galimybes, o informatyvūs tas molekulių struktūras

12 Lietuvių kalba ji pateikta: Tejaras de Šardenas, P. Žmogaus fenomenas. Vilnius: Mintis, 1995.

13 Kuzmickas, B. Katalikiškoji filosofija. XIX ir XX amžiai. Vilnius: Lietuvos teisès universitetas, 2003, p. 252-257.

14 Borinskaja, S. A. Rol geneticheskikh faktorov v socialnoj ehvoliucii [Influence of Genetic Factors in the Social Evolution]. Istorija i sinergetika: metodologija issledovanija [Hystory and Synergetic: methodological investigations]. Mosкva: KomKniga, 2005, s. 63-75. 
organizuojantys elektromagnetiniai (galbūt ir kiti) laukai ${ }^{15}$. Diskusijose dèl tikrovès hierarchinių lygių sąsajų vis labiau ịsitvirtina pažiūra, jog greta kitų mums žinomų priežastingumo tipų egzistuoja visus juos organizuojantis ,žemyneigis“ priežastingumas kaip aukštesniujų ir aukščiausiujų tikrovès lygių įtakos žemesniesiems, jų valdymas ${ }^{16}$. Ir gali būti, kad šis priežastingumo tipas yra sietinas su tuo pirminiu, grynu dvasingumo pavidalu, kuri $\mathrm{P}$. Teilhard de Chardinas pavadino radialine energija.

Bet tai dvasingumo sampratos iki galo nepaaiškina. Todèl drịsiu pateikti savają. Drịsiu teigti, jog dvasingumas yra Šventenybès $p$ a j a u t a-tiek igimta, tiek ịgyta.

\section{Dvasingumas kaip Šventenybès pajauta}

Terminą pajauta vartoju J. Mureikos teikta prasme. Pajauta jis apibrèžia kaip kokio nors reikšmingumo, kurị pripažįstame asmenims, daiktams, meno kūriniams, teoriniams tekstams ar kitokiems religiniams, moraliniams ir t. t. reiškiniams, išgyvenima, ižvalgą ${ }^{17}$. Autorius teigia, kad ,pajautos koncepto įvedimu mėginama atsakyti, kaip atsiranda prasmès santykis su vertybe ir kaip ši iš transcendentinès būsenos ir daikto savaime, iggydama asmeninę prasmę, tampa daiktu mums. Pajauta yra tokia būsena, kuri įveikia susvetimejjusị teorinio atsietumo pavidalą ir atskleidžia tikrąją ir natūralią filosofinès antropologijos bei metafizikos giminystę" ${ }^{\text {"18 }}$.

Atkreipkime dėmesị - čia kalbama ne apie juslinę patirtị, ne apie racionaliai suvokiamus dalykus. Čia kalbama apie tai, ką Hansas Gadameris vadino vidiniu balsu, arba vidine kalba, kuri atsiskleidžia net per tai, kas vadinama ekstrasensorinemis patirtimis: „I šią problematiką mane pastūmėjo paslaptinga ir dažnai sąvokiniu būdu nepaaiškinama bei logiškai neįrodoma tiek ekstrasensorinių, tiek filosofinių ịžvalgų kaip pajautų kilmé“19. J. Mureika įvardija ir kai kuriuos pačius bendriausius pajautos bruožus, juos vadindamas ,paskiromis büsenomis“': simpatija, meile, tolerancija, atsakomybè, pavydas, kančia, laimè, grožis, cinizmas, draugystė, ironija, bjaurumas, komiškumas, juokas, niekšybè, ir t. t. ${ }^{20}$ Egzistuoja ir mastymo pajauta kaip įvykis sąmonèje, apimantis ir transcendenciją, judejjimą bendrybių link, ir atvirkščią kryptị - grịžimą prie savojo Aš per supratimą to, kas mąstoma ${ }^{21}$. Tas ,vidinis balsas“،, arba pajauta, pirmiausiai susijęs su gyvenimo prasmés suvokimu ${ }^{22}$, su tomis žmogiškomis vertybemis, kurias vadiname

15 Gariaev, P. P.; Kokaya, A. A.; Leonova-Gariaeva, E. A.; Muldaschev, E. R.; Smelov, M. V.; Tertishny, G. G.; Ustinova, N. S. Exploration of Wavegenetics and Wave Immunity. DNA Decipher Journal. 2011, 1( 2): $192-217$.

16 Hulswit, M. How Causual is Downward Causation. Journal for General Philosophy of Science. 2005, 36(2): 261-287.

17 Mureika, J. Dvasingumas ir prasmè, supra note 10, p. 46-87.

18 Mureika, J. Pajaustos mintys. Estetikos virsmas estetologija. Vilnius: AB spaustuvė „Spindulys“. 2006, p. 62 .

19 Ibid., p. 54.

20 Ibid.

21 Ibid., p. 75.

22 Mureika, J. Dvasingumas ir prasmè, supra note 10, p. 46-87. 
dorybėmis, ir ypač su tomis žmogiškomis vertybėmis, kurios turi aukščiausiuosius dèmenis.

Vieną iš tų dėmenų vadinu Šventenybės pajauta, ir būtent jos ryškų turejjimą vadinu dvasingumu. Visiškai nesvarbu, kokios profesijos ir kokias karjeros aukštumas žmogus yra pasiekęs arba kaip jam nesiseka gyvenime, bet jeigu jis turi Šventenybès pajautą, jis yra dvasingas. Nesvarbu ir tai, ar žmogus tą Šventenybę supranta Rudolfo Otto teikta prasme, kaip Numinosum, kuris reiškiasi ir per tremendum kaip begalini siaubą prieš nesuvokiamą Nieki, kuris yra Viskas kaip begalinė galia, ir per momentum fascinans, kaip ekstatišką ir kupiną nuolankumo susižavejjimą ta galia.

Žmogus Šventenybę gali pajausti ir itin paprastai - kaip gilia pagarba gyvenimui bei gyvybei, kaip gilią pagarbą žemei, dangui, žmonėms, gyvuliukams, žvèrims ir žvèreliams, žolei ir medžiams, pagaliau pačiam sau ir Tam neapibrèžtam, nenusakomam, iš ko visa yra kilę ir kyla, ką paprastai vadiname Kūreju, Absoliučia Dvasia, Dievu, suteikdami Jam ir kitus pavadinimus.

Tą savo gilią pajauta žmogus gali ir neišsakyti, net negebėti to padaryti, bet jeigu ja vadovaujasi savo veiksmuose, jis yra dvasingas. Ta pajauta nebūtinai susijusi su religiniu tikejjimu, nes jis dažnai būna neišjaustas, dažnai tampa vien tik „duokle“ tradicijai ir papročiams; dažnai būna ir taip, jog vos tik spejjus išeiti iš bažnyčios ar kitos šventovès žmogus ima elgtis taip, tarsi ten nè nebuvęs. Kita vertus, gilus religinis tikejjimas tiesiog neišvengiamai susijęs su Šventenybès pajauta, ir tai nepaprastai veikia žmogaus gyvenimą net tada, kada jis klysta, kada daro niekšybes. Šventenybès pajautą gali turèti net tas žmogus, kuris save laiko ateistu ir ieško gyvenimo prasmès pačiame gyvenime. Bet jau vien tos prasmès paieškos jị daro dvasingą, nes neišvengiamai veda link žinomo klausimo: „Kodèl kažkas yra, o ne nėra? Juk galètų ir nebūti!“‘

\section{Dvasingumo devalvacija ir grižimas prie jo}

Kultūrologinèje dvasingumo sampratoje pabrèžiamas tik žmogaus kūrybingumas, jo gebejimas keisti ir perkeisti pasaulị. Ir būtent šios sampratos ịsivyravime aš regiu esminę dvasingumo devalvacijos priežastį.

Garsioji Protagoro frazè „Žmogus yra visų daiktu matas“, perfrazuota ị ,Žmogus yra visų vertybiu matas“, atrodo, atsigrịžta prieš patị žmogų. Tapdamas ,aukščiausiaja vertybe“, bent jau Vakarų žmogus ima prarasti tai, kas iš tiesų yra aukščiausioji vertybe் - šventenybės kaip pagarbos gyvenimui, pagarbos gyvybei ir Tam, kas tą gyvybę suteikia, pajauta. P a j a u t a kaip betarpiška tikrovès pajautimą, betarpiška gebèjimą atsiverti tai tikrovei, betarpišką gebejjima pajausti net tai, kas juslèms neduota, kas protui atrodo esą neracionalu.

Štai tos Šventenybès pajautos dabartinejje mūsų visuomenejje kaip ir neliko. Šventenybès pajautos kaip neišpasakyto žavèjimosi juslèmis ir protu suvokiamos tikrovès didybe ir nuolankumo prieš ją savo menkumo akivaizdoje.

Pasaulis po mūsų kojomis! Mes esame pasaulio valdovai! Dievas mirè! Ir nieko didingesnio už mus, žmones, nèra! - ir taip galima perteikti garsiają F. Nietsche'ès perfrazuotą, atseit, humanizmo tezę. 
O todèl dingsta visos baimès, dingsta visa pagarba ne tik pirminiam kūrèjui Dievui, bet ir savo žemiškiems kürẻjams - tèvams, genčiai, tautai, valstybei. „Visų vertybių matu“ tampa „nepakartojamas“, „unikalus“ individas. O kadangi tų individų daugiau nei skruzdžių skruzdėlyne ar bičių avilyje, tai ir ,nepakartojamų vertybių“ nesuskaičiuojamas skaičius atsiranda. Tačiau jeigu šitaip atsitiktų su skruzdèmis ar bitėmis, skruzdèlynų ir bitynų bematant neliktų...

Beje, dar O. Spengleris èmé pranašauti, kad taip gali atsitikti ir su žmogiškaisiais skruzdėlynais. Bent jau Vakarų pasaulyje. Ir taip atsitiks, jeigu individualizmas, savęs išsiaukštinimas ir visa tai, ką garbina vadinamieji ,postmodernistai“ ir neoliberalai, dar labiau suklestès. Taip atsitiks, jeigu išnyks šventumo pajauta. Tiesiog $p$ a j a u $t$ a, tiesiog betarpiškas suvokimas, kad mes, žmonès, dar gyvi ir dvasingi esame tik todèl, kad vis dar gebame tikèti, mylèti, gerbti, ilgètis tiesos ir teisybès, ilgètis šventumo.

Mano tvirtu įsitikinimu, net jeigu ir išsipildytų O. Spenglerio pranašystės, jeigu ir žlugtų Vakarų kultūra, dvasingumas nežlugs, neišnyks. Nes jis nepriklauso vien žmogui. Nes tai, ką vadiname dvasingumu ir dvasia, yra pačios tikrovès prigimtyje.

Tačiau labai daug kas priklauso ir nuo mūsų, žmonių. Jau esu atkreipęs dèmesị i tai, kad apie $60 \%$ mūsų elgesio lemia tai, ką R. Descartes'as vadino ,igimtomis idejomis“", arba vartojant šiuolaikinius terminus, lemia genetinis ir socialinis kodai ${ }^{23}$, tad mes jau gimstame su didesniais ar mažesniais gebejimais pajausti. Bet labai daug erdvès lieka ir tos pajautos ugdymui bei ugdymuisi. Būtent tam ir skirta jau minèta monografija „Dvasingumas žmogaus pasaulyje“, tam buvo skirta ir paminèta Švietimo ir mokslo ministerijoje ịvykusi konsultacija-diskusija. Jos metu aš atkreipiau dèmesi i tai, kad nedvasingas žmogus dvasingo neišugdys, o tų dvasingų mūsų švietimo sistemoje ne tiek jau daug. To priežastis paprasta. I pedagogus rengiančius universitetus priimami visi, kas tik geba įstoti, jokios specialios būsimų pedagogų atrankos niekada nebuvo ir nèra. Atrankos ta prasme, kad būtų ịvertinamas ne tik pasirengimas studijuoti (žinios), bet ir motyvacija, o svarbiausia - vertybinés orientacijos, bent svarbiausi anksčiau ịvardinti pajautos bruožai. Pagaliau būtina rimtai $i n$ v e s $t$ u o $t$ i i tokius atrinktus būsimus specialistus, o tam būtina keisti visą tiek studijų, tiek švietimo sistemą, ir pirmiausiai - jų finansavimą.

\section{İžvalgos ir išvados}

1. Dvasingumo problema priklauso filosofinei refleksijai, ir vienu iš perspektyvių šios problemos sprendimo kelių laikytina J. Mureikos pateikta pajautos koncepcija.

2. Ją plètojant siūloma dvasingumą sieti su Šventenybès pajauta.

3. Regima dvasingumo devalvacija sietina su pseudohumanistiniu žmogaus išsiaukštinimu.

4. Siekiant ugdyti dvasingus žmones, būtina keisti visą švietimo sistemą.

23 Kanišauskas, S. „Tabula rasa“ problema ir žmogiškosios vertybès. Socialinių mokslų studijos. 2011, 3(2): $399-408$. 


\section{Literatūra}

Borinskaja, S. A. Rol geneticheskikh faktorov v socialnoj ehvoliuciji [Influence of Genetic Factors in the Social Evolution]. Istorija $i$ sinergetika: metodologicheskije issledovanija [Hystory and Synergetic: methodological investigations]. Moskva: KomKniga, 2005.

Dvasingumas žmogaus pasaulyje. Sudarytojai ir rengejjai J. Kievišas, R. Kondratienè. Vilnius: Vilniaus pedagoginio universiteto leidykla, 2009.

Dvasinis ugdymas:švietimo îstaigu vaidmuo [interaktyvus]. [žiürèta2013-04-22]. <http:// www.smm.lt/strategija/docs/Dvasinis $\% 20$ ugdymas_PROGRAMA_2010-12-21.pdf $>$.

Gariaev, P. P.; Kokaya, A. A.; LeonovaGariaeva, E. A.; Muldaschev, E. R.; Smelov, M. V.; Tertishn,y, G. G.; Ustinova, N. S. Exploration of Wavegenetics and Wave Immunity. DNA Decipher Journal. 2011, 1(2).

Hulswit, M. How Causual is Downward Causation. Journal for General Philosophy of Science. 2005, 36(2).

Jacopozzi, A. Religijos filosofija. Vilnius: Aidai, 1997.

Janulyte, E. Dvasingumo sklaida mažuose miesteliuose. XXI Amžius. 2010 m. balandžio 23 d., Nr. 31 (1816).
Kanišauskas, S. „Tabula rasa“ problema ir žmogiškosios vertybès. Socialiniu moksly studijos. 2011, 3(2).

Kuzmickas, B. Katalikiškoji filosofija. XIX ir $X X$ amžiai. Vilnius: Lietuvos teisès universitetas, 2003.

Mureika, J. Dvasingumas ir prasmè. Dvasingumas žmogaus pasaulyje. Sudarytojai ir rengejai J. Kievišas, R. Kondratienè. Vilnius: Vilniaus pedagoginio universiteto leidykla, 2009.

Mureika, J. Pajaustos mintys. Estetikos virsmas estetologija. Vilnius: AB spaustuvè „Spindulys", 2006.

Oleksiuk, O. Konceptualūs asmenybès dvasingumo formavimo meno srityje pagrindai. Dvasingumas žmogaus pasaulyje. Sudarytojai ir rengejjai J. Kievišas, R. Kondratienè. Vilnius: Vilniaus pedagoginio universiteto leidykla, 2009.

Tejaras de Šardenas, P. Žmogaus fenomenas. Vilnius: Mintis, 1995.

Vaišvila, A. Kultūrologine dvasingumo samprata. Šiuolaikine filosofija: globalizacijos amžius. Sudarytoja ir ats. redaktore J. Morkūnienè. Vilnius: Lietuvos teisès universitetas, 2004.

\section{VALUES IN SPIRITUALITY AND OF SPIRITUALITY}

\section{Saulius Kanišauskas}

Mykolas Romeris University, Lithuania

Summary. The article focuses on the concept of spirituality. It is considered that the concept has undergone four historical stages: biologization, logization, psychologization and culturalization. At present (the stage of culturalization), spirituality is identified with people's creative powers and their abilities to change their immediate environment. However, it is hardly possible to claim that nowadays only the culturological concept of spirituality exists - it is obviously related to the life and mental energy, human feelings and religious experience. 
In attempt to pinpoint the problem of spirituality, Mureika suggested using the conception of pajauta (c.f. feeling). The word pajauta is used rarely in the Lithuanian language and, moreover, it cannot be translated into other languages. It is close to the word "feeling", though it implies extrasensory perception, mental intuitivism and it has to do with the quest for the meaning of life. According to Mureika, the only way to comprehend spiritual values is to feel them. Not cherishing values is one of the major problems of contemporary society. In order to address this problem, Lithuanian academicians held several scientific conferences and organized a meeting at the Ministry of Education and Science. It was concluded that the development of spirituality needs a universal conception. This article attempts to develop such a conception by maintaining that spirituality is pajauta (the feeling) of Divinity, and it is both innate and acquired. The Divinity can be understood as Otto presented, i.e. as Numinosum, or it can be seen as a profound respect for life, human being, and, finally, for the God as the beginning of everything. The process of devaluation of spirituality, which is ongoing in contemporary society, is closely connected with pseudo humanistic apotheosis of a human being and with the ideas of postmodernism and neoliberalism. The article claims that in order to develop spirituality, it is necessary to implement considerable changes in education of future teachers.

Keywords: spirit, spirituality, values, virtue, pajauta (feeling), Divinity.

Saulius Kanišauskas, Mykolo Romerio universiteto Humanitarinių mokslų instituto Filosofijos katedros profesorius. Mokslinių tyrimų kryptys: moralès filosofija, mokslo filosofija.

Saulius Kanišauskas, Mykolas Romeris University, Institute of Humanities, Departament of Philosophy, Professor. Research interests: moral philosophy, science philosophy. 